\title{
Anion dependent formation of linear trinuclear mixed valance cobalt(III/II/III) complexes and mononuclear cobalt(III) complexes of a pyrazole derived ligand - Synthesis, characterization and X-ray structures
}

\author{
Sachindranath Pal ${ }^{\mathrm{a}}$, Anil Kumar Barik ${ }^{\mathrm{b}}$, Samik Gupta ${ }^{\mathrm{c}}$, Somnath Roy ${ }^{\mathrm{c}}$, \\ Tarak Nath Mandal ${ }^{\mathrm{c}}$, Arijit Hazra ${ }^{\mathrm{c}}$, Mohamed Salah El Fallah ${ }^{\mathrm{d}, *}$, Ray J. Butcher ${ }^{\mathrm{e}}$, \\ Shie-Ming Peng ${ }^{\mathrm{f}}$, Gene-Hsiang. Lee ${ }^{\mathrm{f}}$, Susanta Kumar Kar ${ }^{\mathrm{c}, *}$ \\ ${ }^{a}$ Department of Chemistry, Sree Chaitanya College, Habra, North 24 Parganas, West Bengal, India \\ ${ }^{\mathrm{b}}$ Department of Chemistry, St. Paul's C.M. College, 33/1, Raja Rammohan Roy Sarani, Calcutta 700 009, India \\ ${ }^{\mathrm{c}}$ Department of Chemistry, University College of Science, 92 A.P.C. Road, Calcutta 700 009, India \\ d Departament de Química Inorgànica, Facultat de Química, Universitat de Barcelona, Martí i Franquès 1-11, 08028 Barcelona, Spain

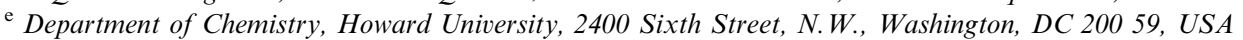 \\ ${ }^{\mathrm{f}}$ Department of Chemistry, National Taiwan University, Taipei 106, Taiwan, ROC
}

Received 4 July 2007; accepted 20 September 2007

\begin{abstract}
Trinuclear mixed oxidation state Co(III/II/III) complexes with a different coordination geometry at each cobalt center of a pyrazole derived Schiff base and mononuclear cobalt (III) complexes of another pyrazole containing Schiff base having N-donor atoms have been prepared and structurally characterized. Reaction of 5-methyl-3-formylpyrazole (MPA) and 1,3-diamino-2-propanol (DAP) with CoX 2 . $6 \mathrm{H}_{2} \mathrm{O}(\mathrm{X}=\mathrm{Cl}, \mathrm{Br})$ in a 2:1:1 ratio produces unusual trinuclear mixed-valent complexes $\left[\mathrm{Co}_{3}\left(\mathrm{~L}_{1}\right)_{2} \mathrm{Cl}_{4}\right](\mathbf{1})$ and $\left[\mathrm{Co}_{3}\left(\mathrm{~L}_{1}\right)_{2} \mathrm{Br}_{4}\right](\mathbf{2})[$ where $\mathrm{H}_{2} \mathrm{~L}_{1}=1$, 3-bis(5-methyl-3-formylpyrazolylmethinimino)propane-2-ol], and the same reaction when carried out with $\mathrm{CoX}_{2} \cdot 6 \mathrm{H}_{2} \mathrm{O}$ $\left(\mathrm{X}=\mathrm{CH}_{3} \mathrm{COO}^{-}, \mathrm{ClO}_{4}^{-} \mathrm{NO}_{3}^{-}, \mathrm{BF}_{4}^{-}\right)$produces mononuclear $\left[\mathrm{Co}\left(\mathrm{L}_{1}\right)\left(\mathrm{H}_{2} \mathrm{O}\right)_{2}\right] \mathrm{X} \cdot \mathrm{H}_{2} \mathrm{O}$, of which only $\left[\mathrm{Co}\left(\mathrm{L}_{1}\right)\left(\mathrm{H}_{2} \mathrm{O}\right)_{2}\right] \mathrm{CH}_{3} \mathrm{COO} \cdot \mathrm{H}_{2} \mathrm{O}$ (3) was isolated. In contrast, the reaction of 5-methyl-3-formylpyrazole (MPA) and 1,3-diamino-2-propanol (DAP) with $\mathrm{CoX}_{2} \cdot 6 \mathrm{H}_{2} \mathrm{O}$ (where $\mathrm{X}=\mathrm{ClO}_{4}^{-} \mathrm{NO}_{3}^{-}, \mathrm{BF}_{4}^{-}$) in a 1:1:1 ratio produces mononuclear Schiff base complexes $\left[\mathrm{Co}(\mathrm{L})_{2}\right] \mathrm{ClO} \mathrm{O}_{4}(\mathbf{4}),\left[\mathrm{Co}(\mathrm{L})_{2}\right] \mathrm{NO}_{3}(\mathbf{5})$ and $\left[\mathrm{Co}(\mathrm{L})_{2}\right] \mathrm{BF}_{4}(6)$ [where $\mathrm{HL}=1$-(5-methyl-3-formylpyrazolylmethinimino)-3-aminopropane-2-ol], whereas when $\mathrm{X}=\mathrm{Cl}$ and $\mathrm{Br}$ a hygroscopic intractable material was isolated. Among the above species, $\mathbf{1}$ and $\mathbf{4}$ have been crystallographically characterized. In $\mathbf{1}$, three cobalt atoms are arranged in a linear fashion and are bridged through pyrazolate rings. The terminal diamagnetic low spin cobalt(III) ions with a $\mathrm{N}_{4} \mathrm{Cl}_{2}$ chromophore are in a distorted octahedral environment. These two outer cobalt(III) complexes individually act as bidentate chelating ligands and encapsulate the central cobalt(II) ion, which adopts a distorted flattened, tetrahedral geometry with a $\mathrm{N}_{4}$ chromophore. The interatomic separations are $3.794 \AA(\mathrm{Co} 1 \cdots \mathrm{Co} 2)$ and $3.791 \AA$ (Co2 ‥ Co3). In 4, the cobalt(III) atom is also in a distorted octahedral geometry with a $\mathrm{N}_{6}$ chromophore. Variable temperature (300-2 K) magnetic susceptibility measurements have been carried out for 1 and 2. Zero field splitting of the tetrahedral cobalt(II) ion has been noticed. The EPR spectrum of $\mathbf{1}$ and $\mathbf{2}$ at low temperature is associated with a Kramer doublet $\pm 1 / 2$ arising from the $S=3 / 2$ ground state. Some of the complexes are further characterized by UV-Vis, IR and electrochemical studies. The IR spectrum of 3 shows the typical vibration of ionic acetate at $1577 \mathrm{~cm}^{-1}\left(v_{\mathrm{asym}}\right) \mathrm{and} 1397 \mathrm{~cm}{ }^{-1}\left(v_{\mathrm{sym}}\right)$.
\end{abstract} (c) 2007 Elsevier Ltd. All rights reserved.

Keywords: Trinuclear mixed oxidation state pyrazole bridged cobalt complexes; Schiff bases; X-ray structures; Magnetic properties; EPR spectra

\footnotetext{
${ }^{*}$ Corresponding authors. Tel.: +91033 24322936; fax: +91 03323519755.

E-mail addresses: Salah.elfallah@qi.ub.es (M.S. El Fallah), skkar_cu@yahoo.co.in (S.K. Kar).
} 


\section{Introduction}

Multinuclear transition metal complexes have become a central theme of current research because of their potentially useful properties in the realm of relevant scientific and technological fields. They are involved in some notable catalytic processes [1]. Their important use for modelling the metal active sites of metalloproteins [2] and also their recent applications in the area of nanoscale materials [3] have drawn the focal point of attraction of modern chemists towards the synthesis and characterization of such metal complexes. Especially, there is currently a great deal of interest in the synthesis and characterization of polynuclear cobalt complexes due to their wide-ranging potential applications such as catalysts [4], electron transfer mediators in dye-sensitized solar cells [5], anti-viral agents [6] and molecular nano-magnets [7]. In particular, trinuclear cobalt complexes draw their speciality from their use as catalysts in epoxidation of olefins [8] and in the autoxidation of hydrocarbons [9]. One of the synthetic strategies to prepare polynuclear transition metal complexes is the use of simple metal ion complexes which have the appropriate functionality to act as ligands for another metal ion or ions. The speciality of these strategies is the use of a mononuclear transition metal complex as a bidentate chelate for a second metal ion. One attractive feature of this scheme is that the second metal ion will usually be in a different coordination pocket from the first one, potentially allowing the facile synthesis of homonuclear complexes in which the metals having different oxidation states are in different geometries.

Studies in metal ion mediated anion dependent formation of polynuclear Schiff base complexes has been one of the prime topics of our recent research [10]. In continuation of our earlier work, attempts have been made to prepare $\mathrm{Co}(\mathrm{II})$ complexes of the Schiff base ligand $\mathrm{H}_{2} \mathrm{~L}_{1}[2: 1$ condensation product of MPA (5-methyl-3-formylpyrazole) and DAP (1,3-diamino-2-propanol)], employing the template methodology. Interestingly, when 2 equiv. of MPA and 1 equiv. of DAP are condensed in the presence of 1 equiv. of $\mathrm{Co}$ (II) chloride/bromide, the unusual mixed oxidation state pyrazolate bridged complexes $\left[\mathrm{Co}_{3^{-}}\right.$ $\left.\left(\mathrm{L}_{1}\right)_{2} \mathrm{X}_{4}\right], \mathrm{X}=\mathrm{Cl}, \mathrm{Br}(\mathbf{1}$ and $\mathbf{2})$ are isolated. Under similar conditions $\mathrm{CoX}_{2} \cdot 6 \mathrm{H}_{2} \mathrm{O}\left(\mathrm{X}=\mathrm{CH}_{3} \mathrm{COO}^{-}, \mathrm{ClO}_{4}^{-}, \mathrm{NO}_{3}{ }^{-}\right.$, $\left.\mathrm{BF}_{4}{ }^{-}\right)$produces the mononuclear complexes $\left[\mathrm{Co}\left(\mathrm{L}_{1}\right)^{-}\right.$ $\left.\left(\mathrm{H}_{2} \mathrm{O}\right)_{2}\right] \mathrm{X} \cdot \mathrm{H}_{2} \mathrm{O}$, of which only the acetate complex (3) $\left[\mathrm{X}=\mathrm{CH}_{3} \mathrm{COO}^{-}\right]$was isolated; the other products being intractable materials that could not be isolated. In contrast, the same reaction when carried out in MPA and DAP in a 2:2 equiv. ratio in the presence of 1 equiv. of $\mathrm{CoX}_{2} \cdot 6 \mathrm{H}_{2} \mathrm{O}\left(\mathrm{X}=\mathrm{ClO}_{4}^{-}, \mathrm{NO}_{3}^{-}\right.$and $\left.\mathrm{BF}_{4}^{-}\right)$ended in forming the desired mononuclear Schiff base complexes $\left[\mathrm{Co}(\mathrm{L})_{2}\right] \mathrm{X}\left(\mathrm{X}=\mathrm{ClO}_{4}^{-}, \mathrm{NO}_{3}^{-}\right.$and $\left.\mathrm{BF}_{4}^{-}\right)(\mathbf{4}, 5$ and 6$)$. An intractable green mass was obtained in the same reaction when $\mathrm{Cl}^{-} / \mathrm{Br}^{-}$were used as counterions. The structures of the ligands $\mathrm{H}_{2} \mathrm{~L}_{1}$ and $\mathrm{HL}$ are given in Fig. 1 .

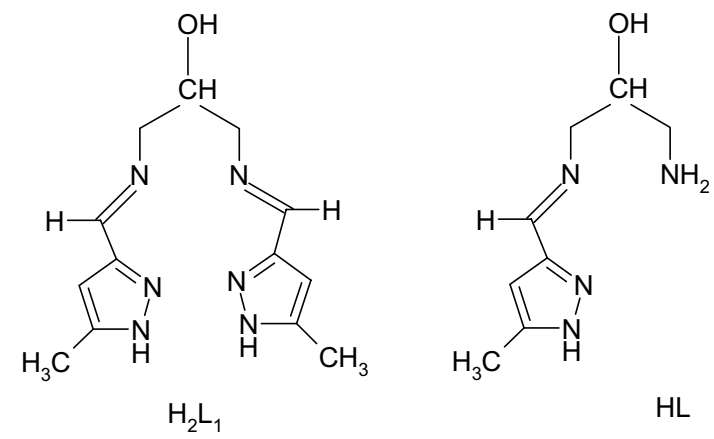

Fig. 1. Structure of the ligands.

All the observations are depicted in Scheme 1 for clarity.

\section{Experimental}

\subsection{Materials}

1,3-Diamino-2-propanol (DAP) was purchased from Aldrich, USA. 5-Methyl-3-formylpyrazole (MPA) was synthesized as described earlier [11]. Spectrograde solvents were used for physical measurements. All the other reagents and solvents were purchased from commercial sources and purified by standard procedures [12].

Synthesis: Warning! Perchlorate salts are potentially explosive and were handled only in small quantities with care.

\subsection{Preparation of the $\mathrm{Co}(\mathrm{III} / \mathrm{II})$ complexes $\left[\mathrm{Co}_{3}\left(\mathrm{~L}_{1}\right)_{2} \mathrm{X}_{4}\right]$ $\left[X=\mathrm{Cl}^{-}(1), \mathrm{Br}^{-}(2)\right]$}

A mixture of MPA $(0.22 \mathrm{~g}, 2 \mathrm{mmol})$ and DAP $(0.09 \mathrm{~g}$, $1 \mathrm{mmol}$ ) was refluxed for $4 \mathrm{~h}$ in $50 \mathrm{ml}$ dry ethanol. The light red solution was filtered off, cooled to room temperature and the corresponding $\mathrm{Co}$ (II) salt $(1 \mathrm{mmol})$ was added. Immediately a green precipitate was separated. The mixture was stirred for $2 \mathrm{~h}$ and filtered. The precipitate was washed with ethanol and dried over fused $\mathrm{CaCl}_{2}$ in a desiccator. Yield 58\% (1), 53\% (2). X-ray quality crystals of 1 were grown by slow diffusion of $n$-hexane into a dichloromethane-ethanol $(1: 1 \mathrm{~V} / \mathrm{V}$ mixture $)$ solution of the compound.

Anal. Calc. for $\mathrm{C}_{26} \mathrm{H}_{32} \mathrm{Cl}_{4} \mathrm{Co}_{3} \mathrm{~N}_{12} \mathrm{O}_{2}$ (1): C, 36.16; H, 3.70; N, 16.46. Found: C, 36.32; H, 3.73; N, 15.23\%. IR $\left(\mathrm{KBr} ; \mathrm{cm}^{-1}\right): 3400,3190,2979\left(v_{\mathrm{OH}}, v_{\mathrm{NH}}\right), 1605\left(v_{\mathrm{C}=\mathrm{Niminyl}}\right)$, $1521\left(v_{\mathrm{C}=\mathrm{NPz}}\right), 1035\left(v_{\mathrm{N}-\mathrm{NPz}}\right)$. Diffuse reflectance spectroscopy $(\mathrm{DRS})\left(\lambda_{\max }, \mathrm{nm}\right): 1065,644,630,590 . \mathrm{UV}-\mathrm{V}$ is $(\mathrm{MeOH})\left(\lambda_{\max }, \mathrm{nm}\right)\left(\varepsilon, 1 \mathrm{M}^{-1} \mathrm{~cm}^{-1}\right): 1075(51), 587$ (286), 565 (254), 542 (183). Molar conductivity (MeOH solution): $\Lambda_{\mathrm{M}}=16 \Omega^{-1} \mathrm{~cm}^{2} \mathrm{~mol}^{-1}$. Magnetism (solid state, room temperature): $\mu_{\mathrm{eff}}=4.3$ B.M.

Anal. Calc. for $\mathrm{C}_{26} \mathrm{H}_{32} \mathrm{Br}_{4} \mathrm{Co}_{3} \mathrm{~N}_{12} \mathrm{O}_{2}$ (2): C, 29.98; H, 3.07; N, 16.14. Found: C, 29.76; H, 3.19; N, 15.91\%. IR 


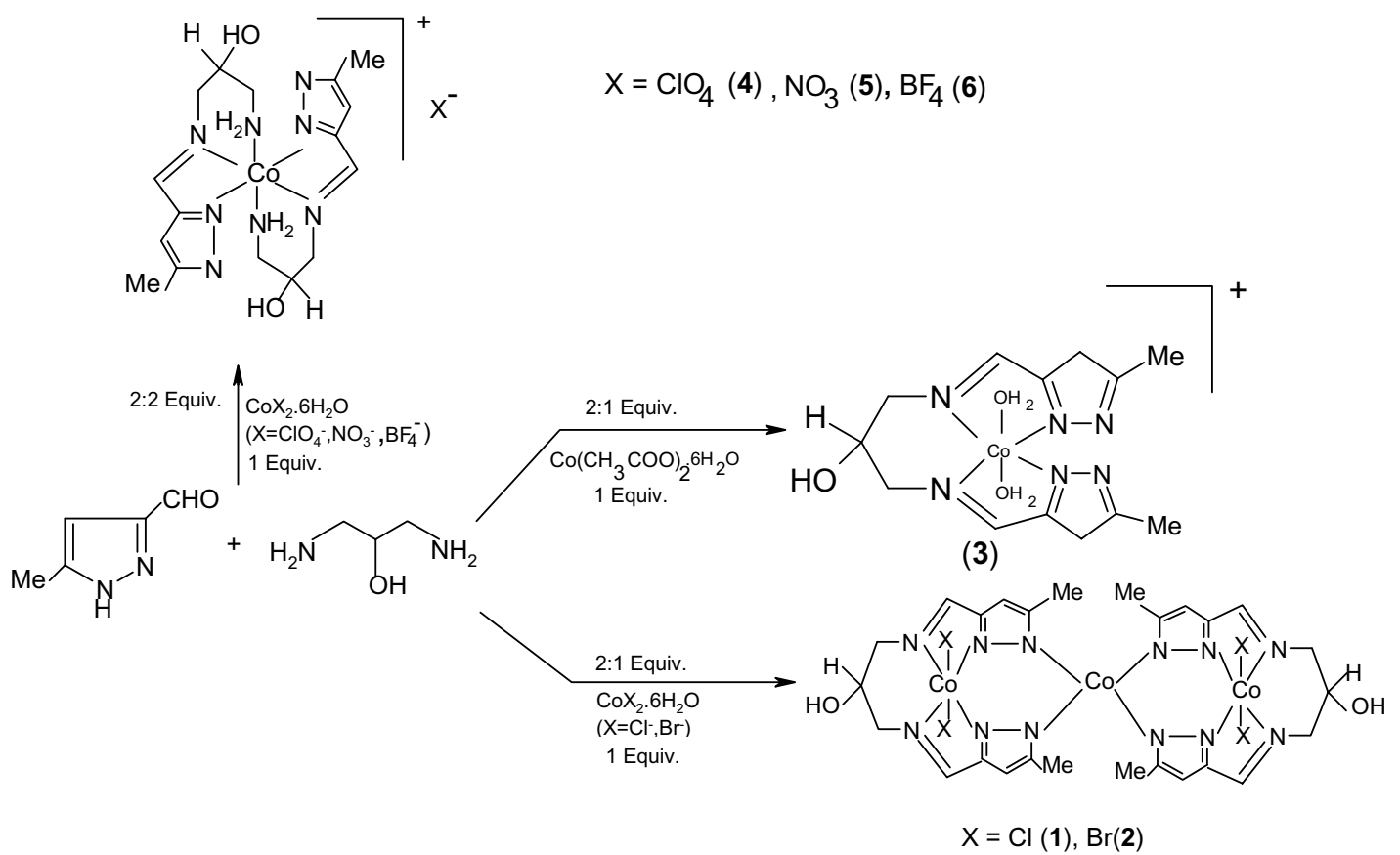

Scheme 1.

$\left(\mathrm{KBr} ; \mathrm{cm}^{-1}\right): 3401,3210,3100\left(v_{\mathrm{OH}}, v_{\mathrm{NH}}\right), 1603\left(v_{\mathrm{C}=\text { Niminyl }}\right)$, $1523\left(v_{\mathrm{C}=\mathrm{NPz}}\right), 1040\left(v_{\mathrm{N}-\mathrm{NPz}}\right)$. Diffuse reflectance spectroscopy (DRS) $\left(\lambda_{\max }, \mathrm{nm}\right): 1073,645,629,598$. UV-Vis (DMF) $\left(\lambda_{\max }, \mathrm{nm}\right)\left(\varepsilon, 1 \mathrm{M}^{-1} \mathrm{~cm}^{-1}\right): 1060$ (65), 648 (795), 625 (732), 595 (565). Molar conductivity (DMF solution): $\Lambda_{\mathrm{M}}=52 \Omega^{-1} \mathrm{~cm}^{2} \mathrm{~mol}^{-1}$. Magnetism (solid state, room temperature): $\mu_{\mathrm{eff}}=4.2$ B.M.

\subsection{Preparation of $\left[\mathrm{Co}\left(\mathrm{L}_{1}\right)\left(\mathrm{H}_{2} \mathrm{O}\right)_{2}\right] \mathrm{CH}_{3} \mathrm{COO} \cdot \mathrm{H}_{2} \mathrm{O}$ (3)}

To a filtered solution of a mixture of MPA $(0.22 \mathrm{~g}$, $2 \mathrm{mmol})$ and DAP $(0.09 \mathrm{~g}, 1 \mathrm{mmol})$ in $30 \mathrm{ml}$ dry ethanol, prepared following the same procedure outlined above, the cobalt(II) salt $\mathrm{Co}(\mathrm{II}) \mathrm{X}_{2} \cdot \mathrm{xH}_{2} \mathrm{O}(1 \mathrm{mmol})$ was added $\left(\mathrm{X}=\mathrm{ClO}_{4}^{-}, \mathrm{BF}_{4}^{-}, \mathrm{CH}_{3} \mathrm{COO}^{-}, \mathrm{NO}_{3}^{-}\right)$. The solution in each case was refluxed for $4 \mathrm{~h}$ to get a red solution. Only the complex with acetate as a counterion has been isolated, while in all other cases hygroscopic intractable materials were found. In spite of our several attempts, we were unsuccessful to isolate the X-ray quality crystals of 3 .

Anal. Calc. for $\mathrm{C}_{15} \mathrm{H}_{25} \mathrm{CoN}_{6} \mathrm{O}_{6}(3): \mathrm{C}, 40.54 ; \mathrm{H}, 5.68 ; \mathrm{N}$ $18.92 \%$. Found: C, $40.51 ; \mathrm{H}, 5.20$; N, $18.45 \%$. IR ( $\mathrm{KBr}$; $\left.\mathrm{cm}^{-1}\right)$ : 3600-2900 (v.b.) ( $\left.v_{\mathrm{OH}}, v_{\mathrm{H}_{2} \mathrm{O}}, v_{\mathrm{NH}}\right), 1610\left(v_{\mathrm{C}=\text { Niminyl }}\right)$, $1577\left(v_{\mathrm{C}=\mathrm{NPz}}\right.$ and $\left.v_{\text {ionic acetate }}\right), 1397\left(v_{\text {ionic acetate }}\right)$. Diffuse reflectance spectroscopy (DRS) $\left(\lambda_{\max }, \mathrm{nm}\right): 462,373$. UVVis $(\mathrm{MeOH})\left(\lambda_{\max }, \mathrm{nm}\right)\left(\varepsilon, 1 \mathrm{M}^{-1} \mathrm{~cm}^{-1}\right): 505$ (12). Molar conductivity (MeOH solution): $\Lambda_{\mathrm{M}}=82 \Omega^{-1} \mathrm{~cm}^{2} \mathrm{~mol}^{-1}$. Magnetism (solid state, room temperature): $\mu_{\mathrm{eff}}=0$. TGA: Loss of lattice water (calc. $4.05 \%$, found $4.12 \%$ ) in the temperature range $75-85^{\circ} \mathrm{C}$ and that of the coordinated water molecules (calc. $8.1 \%$, found $7.98 \%$ ) in the temperature range $170-195^{\circ} \mathrm{C}$.
2.4. Preparation of $\mathrm{Co}(\mathrm{III})$ complexes with $\mathrm{HL}$ : $\left[\mathrm{Co}(L)_{2}\right] X\left[\mathrm{X}=\mathrm{ClO}_{4}^{-}(4), \mathrm{NO}_{3}^{-}(5), \mathrm{BF}_{4}^{-}(6)\right]$

A mixture of MPA $(0.11 \mathrm{~g}, 1 \mathrm{mmol})$ and DAP $(0.09 \mathrm{~g}$, $1 \mathrm{mmol}$ ) was refluxed for $4-5 \mathrm{~h}$ in ethanol. To the light yellow filtrate, an ethanolic solution of the corresponding $\mathrm{CoX} 2 \cdot 6 \mathrm{H}_{2} \mathrm{O}\left(\mathrm{X}=\mathrm{ClO}_{4}^{-}, \mathrm{NO}_{3}^{-}, \mathrm{BF}_{4}^{-}\right)(1 \mathrm{mmol})$ was added and again refluxed for $4 \mathrm{~h}$. The resulting deep red solution was left for slow evaporation at room temperature in a fused $\mathrm{CaCl}_{2}$ desiccator. After 5 days red coloured crystalline compounds were isolated. Yield $60-65 \%$. X-ray quality crystals of $\mathbf{4}$ were grown by the slow evaporation of a methanolic solution of the compound.

Anal. Calc. for $\mathrm{C}_{16} \mathrm{H}_{26} \mathrm{CoN}_{8} \mathrm{ClO}_{6}$ (4): C, 36.92; H, 5.03; N, 21.50. Found: C, 36.10; H, 4.98; N, 21.22\%. IR $\left(\mathrm{KBr}: \mathrm{cm}^{-1}\right)$ : 3320 (br) $\left(v_{\mathrm{OH}}, v_{\mathrm{NH}}\right), 1602\left(v_{\mathrm{C}=\mathrm{N}(\text { iminyl })}\right)$, $1563\left(\mathrm{~s}, v_{\mathrm{C}=\mathrm{NPz}}\right), 1095(\mathrm{~s})\left(v_{\mathrm{ClO} 4}\right) 1010\left(v_{\mathrm{N}-\mathrm{NPz}}\right)$. Diffuse reflectance spectroscopy (DRS) $\left(\lambda_{\max }, \mathrm{nm}\right): 368,453$. UV-Vis (DMF), $\lambda_{\max }, \mathrm{nm}\left(\varepsilon, 1 \mathrm{M}^{-1} \mathrm{~cm}^{-1}\right): 449$ (35). Molar conductivity (DMF solution): $\Lambda_{\mathrm{M}}=80 \Omega^{-1}$ $\mathrm{cm}^{2} \mathrm{~mol}^{-1}$.

Anal. Calc. for $\mathrm{C}_{16} \mathrm{H}_{26} \mathrm{CoN}_{9} \mathrm{O}_{5}(\mathbf{5})$ : C, 39.75; H, 5.38; N, 26.08. Found: C, 40.01; H, 5.21; N, 26.03\%. IR (KBr: $\left.\mathrm{cm}^{-1}\right)$ : 3322 (br) $\left(v_{\mathrm{OH}}, v_{\mathrm{NH}}\right), 1609\left(v_{\mathrm{C}=\mathrm{N}(\text { iminyl })}\right), 1563(\mathrm{~s}$, $\left.v_{\mathrm{C}=\mathrm{NPz}}\right), 1010\left(v_{\mathrm{N}-\mathrm{NPz}}\right)$. Diffuse reflectance spectroscopy (DRS) $\left(\lambda_{\max }, \mathrm{nm}\right): 370,453 . \mathrm{UV}-\mathrm{Vis}(\mathrm{DMF})\left(\lambda_{\max }, \mathrm{nm}\right)$ $\left(\varepsilon, 1 \mathrm{M}^{-1} \mathrm{~cm}^{-1}\right)$ : 448 (35). Molar conductivity (DMF solution): $\Lambda_{\mathrm{M}}=76 \Omega^{-1} \mathrm{~cm}^{2} \mathrm{~mol}^{-1}$.

Anal. Calc. for $\mathrm{C}_{16} \mathrm{H}_{26} \mathrm{CoN}_{8} \mathrm{O}_{2} \mathrm{BF}_{4}$ (6): C, 37.79; H, 5.11; N, 22.04. Found: C, 37.12; H, 5.02; N, 21.15\%. IR $\left(\mathrm{KBr}: \mathrm{cm}^{-1}\right)$ : 3322 (br) $\left(v_{\mathrm{OH}}, v_{\mathrm{NH}}\right), 1609\left(v_{\mathrm{C}=\mathrm{N}(\text { iminyl })}\right)$, 
$1563\left(\mathrm{~s}, v_{\mathrm{C}=\mathrm{NPz}}\right), 1011\left(v_{\mathrm{N}-\mathrm{NPz}}\right)$. Diffuse reflectance spectroscopy (DRS) $\left(\lambda_{\max }, \mathrm{nm}\right): 370,453$. UV-Vis (DMF) $\left(\lambda_{\max }, \mathrm{nm}\right)\left(\varepsilon, 1 \mathrm{M}^{-1} \mathrm{~cm}^{-1}\right): 445$ (35). Molar conductivity (DMF solution): $\Lambda_{\mathrm{M}}=82 \Omega^{-1} \mathrm{~cm}^{2} \mathrm{~mol}^{-1}$.

\subsection{Physical methods}

Infrared spectra were recorded on $\mathrm{KBr}$ disks (4000$400 \mathrm{~cm}^{-1}$ ) with a Perkin-Elmer FTIR spectrophotometer. UV-Vis spectra were measured on a Hitachi U-3501 spectrophotometer. Room temperature magnetic moments were measured with a vibrating sample magnetometer. Variable temperature susceptibility measurements for $\mathbf{1}$ and $\mathbf{2}$ were carried out on polycrystalline samples at the Servei de Magnetoquimica of the Universitat de Barcelona with a Quantum Design SQUID MPMS-XL susceptometer apparatus working in the range $2-300 \mathrm{~K}$ under a magnetic field of approximately $200 \mathrm{G}(2-30 \mathrm{~K})$ and $5000 \mathrm{G}$ (35$300 \mathrm{~K})$. Diamagnetic corrections were estimated from Pascal Tables. The EPR spectra have been recorded on an X-band Bruker spectrometer (ESR 300E) working with an Oxford helium liquid cryostat for variable temperature measurements. The diffuse reflectance spectra of the reported complexes were recorded on a Hitachi U-3501 spectrophotometer. Electrical conductivity measurements were carried out in methanol solution using a Systronics model 304 digital conductivity meter. Elemental analyses were carried out at IACS, Calcutta with a Perkin-Elmer model $2400 \mathrm{CHN}$ analyzer. Cyclic voltammetry was carried out using Sycopel model AEW2 1820F/S instrument. The measurements were performed at $300 \mathrm{~K}$ in DMF solutions containing $0.2 \mathrm{M}$ TEAP and $10^{-3}-10^{-4} \mathrm{M}$ cobalt complex 1 deoxygenated by bubbling with nitrogen. The working, counter and reference electrodes used were a platinum wire, a platinum coil and an SCE.

\subsection{X-ray crystal structure analysis}

Selected crystal data for $\mathbf{1}$ and $\mathbf{4}$ are given in Table 1 . Data collections were made using a Bruker SMART $\mathrm{CCD}$ area detector (for $\mathbf{1}$ ) and a Bruker $\mathrm{P} 4$ diffractometer (for 4) equipped with a graphite monochromated Mo K $\alpha$ radiation $(\lambda=0.71073 \AA)$ source in the $\omega$ scan mode at 295(2) and 293(2) K, respectively. Cell parameter refinement and data reduction for $\mathbf{1}$ were carried out using the Bruker SAINT program [13]. For 4, cell parameters were refined by Bruker XSCANS and the corresponding data reduction were done by Bruker SHELXTL software [14]. The structures were solved by conventional direct methods and refined by full-matrix least square methods using $F^{2}$ data. SHELXs-97 and SHELXL-97 programs [15] were used for structure solution and refinement, respectively. Positions of $\mathrm{H}$-atoms were treated as riding on their parent atoms. For $\mathbf{4}$, this was a room temperature structure containing perchlorate. As is usual for this group, it was disordered. However, an added complication was that this group was also near a symmetry element. This made it
Table 1

Crystallographic data and structure refinements for $\mathbf{1}$ and $\mathbf{4}$

\begin{tabular}{|c|c|c|}
\hline Complex & 1 & 4 \\
\hline Empirical formula & $\mathrm{C}_{26} \mathrm{H}_{32} \mathrm{Cl}_{4} \mathrm{Co}_{3} \mathrm{~N}_{12} \mathrm{O}_{2}$ & $\mathrm{C}_{16} \mathrm{H}_{26} \mathrm{ClCoN}_{8} \mathrm{O}_{6}$ \\
\hline Formula weight & 863.23 & 520.83 \\
\hline Temperature (K) & $295(2)$ & $293(2)$ \\
\hline Wavelength $(\AA)$ & 0.71073 & 0.71073 \\
\hline Crystal system & monoclinic & monoclinic \\
\hline Space group & $C 2 / c$ & $C 2 / c$ \\
\hline \multicolumn{3}{|l|}{ Unit cell dimensions } \\
\hline$a(\AA)$ & $35.5966(13)$ & $10.5408(9)$ \\
\hline$b(\AA)$ & $8.1847(3)$ & $12.0131(10)$ \\
\hline$c(\AA)$ & $32.8940(12)$ & $17.8896(16)$ \\
\hline$\beta\left({ }^{\circ}\right)$ & $120.384(2)$ & $95.378(5)$ \\
\hline Volume & $8267.3(10)$ & $2255.3(3)$ \\
\hline$Z$ & 8 & 4 \\
\hline$D_{\text {calc }}\left(\mathrm{Mg} / \mathrm{m}^{3}\right)$ & 1.387 & 1.534 \\
\hline $\begin{array}{l}\text { Absorption coefficient } \\
\left(\mathrm{mm}^{-1}\right)\end{array}$ & 1.486 & 0.929 \\
\hline$F(000)$ & 3496 & 1080 \\
\hline Crystal size (mm) & $0.35 \times 0.10 \times 0.02$ & $0.10 \times 0.70 \times 0.26$ \\
\hline $\begin{array}{l}\theta \text { Range for data collection } \\
\left({ }^{\circ}\right)\end{array}$ & $1.33-25.00$ & $2.29-27.49$ \\
\hline Limiting indices & $\begin{array}{l}-42 \leqslant h \leqslant 42 \\
-9 \leqslant k \leqslant 9 \\
-39 \leqslant 1 \leqslant 35\end{array}$ & $\begin{array}{l}0 \leqslant h \leqslant 11 \\
0 \leqslant k \leqslant 15 \\
-23 \leqslant 1 \leqslant 23\end{array}$ \\
\hline Reflections collected & 27333 & 2588 \\
\hline Independent reflections $\left[R_{\text {int }}\right]$ & $7285[0.1215]$ & $2452[0.0194]$ \\
\hline $\begin{array}{l}\text { Completeness to } \theta=27.50^{\circ} \\
\quad(\mathbf{1}), 25.00^{\circ}(\mathbf{4})\end{array}$ & $99.9 \%$ & $97.3 \%$ \\
\hline Absorption correction & $\begin{array}{l}\text { semi-empirical from } \\
\text { equivalents }\end{array}$ & empirical \\
\hline $\begin{array}{l}\text { Maximum and minimum } \\
\text { transmission }\end{array}$ & 0.9709 and 0.6242 & 0.2864 and 0.2421 \\
\hline Refinement method & $\begin{array}{l}\text { full-matrix least- } \\
\text { squares on } F^{2}\end{array}$ & $\begin{array}{l}\text { full-matrix least- } \\
\text { squares on } F^{2}\end{array}$ \\
\hline Data/restraints/parameters & $7285 / 8 / 418$ & $2452 / 7 / 165$ \\
\hline Goodness-of-fit on $F^{2}$ & 1.050 & 1.059 \\
\hline Final $R$ indices $[I>2 \sigma(I)]$ & $\begin{array}{l}R_{1}=0.0957 \\
w R_{2}=0.2765\end{array}$ & $\begin{array}{l}R_{1}=0.0589 \\
w R_{2}=0.1635\end{array}$ \\
\hline$R$ indices (all data) & $\begin{array}{l}R_{1}=0.1977 \\
w R_{2}=0.3495\end{array}$ & $\begin{array}{l}R_{1}=0.0758 \\
w R_{2}=0.1808\end{array}$ \\
\hline $\begin{array}{l}\text { Largest differences in peak } \\
\quad \text { and hole }\left(\mathrm{e} \AA^{-3}\right)\end{array}$ & 0.448 and -0.783 & 1.040 and -0.614 \\
\hline
\end{tabular}

much harder to idealize this group during the refinement process. Because of symmetry one $\mathrm{O}$ atom was in two positions. The best model was obtained by constraining the $\mathrm{Cl}-\mathrm{O}$ distance and the $\mathrm{O}-\mathrm{O}$ separation.

\section{Results and discussion}

The Schiff base ligand $\mathrm{H}_{2} \mathrm{~L}_{1}$, acting as a binegative hexadentate ligand, forms linear trinuclear pyrazolate bridged mixed valent cobalt complexes $\left[\mathrm{Co}_{3}\left(\mathrm{~L}_{1}\right)_{2} \mathrm{Cl}_{4}\right](\mathbf{1})$ and $\left[\mathrm{Co}_{3}\left(\mathrm{~L}_{1}\right)_{2} \mathrm{Br}_{4}\right](2)$ in the presence of the $\mathrm{Cl}^{-}$and $\mathrm{Br}^{-}$anion, respectively. The same ligand forms mononuclear complexes $\left[\mathrm{Co}\left(\mathrm{L}_{1}\right)\left(\mathrm{H}_{2} \mathrm{O}\right)_{2}\right] \mathrm{X} \cdot \mathrm{H}_{2} \mathrm{O}$ for other anions like $\mathrm{CH}_{3} \mathrm{COO}^{-}(3), \mathrm{ClO}_{4}^{-}, \mathrm{NO}_{3}^{-}$and $\mathrm{BF}_{4}^{-}$, where it acts as a tetradentate binegative ligand. The other Schiff base HL, functioning as a uninegative tridentate ligand, forms mononuclear complexes $\left[\mathrm{Co}(\mathrm{L})_{2}\right] \mathrm{ClO}_{4}(4),\left[\mathrm{Co}(\mathrm{L})_{2}\right] \mathrm{NO}_{3}$ 
(5) and $\left[\mathrm{Co}(\mathrm{L})_{2}\right] \mathrm{BF}_{4}(\mathbf{6})$. The crystal structures of $\mathbf{1}$ and $\mathbf{3}$ are depicted below.

\subsection{Description of crystal structures}

Fig. 2 shows a perspective view of compound 1 including the atom numbering scheme. The crystal data and selected bond lengths along with angles are presented in Tables 1 and 2, respectively. The crystal structure reveals the formation of a neutral, linear, trinuclear complex with mixed oxidation states of cobalt. The trinuclear cobalt complex locates at a general position in $C 2 / c$, there is no crystallographic symmetry in the complex. The hydroxyl group attached to $\mathrm{C} 7$ is disordered at the axial and equatorial positions with half occupancies. The other sites of the six-membered ring (Co3-N9-C19-C20-C21-N10) are seriously disordered on $\mathrm{C} 20, \mathrm{C} 21$ and $\mathrm{O} 1$ with half occupancies. Some restraints are applied in the refinement. The difference in bond lengths discriminate between the $\mathrm{Co}(\mathrm{II})$ and $\mathrm{Co}$ (III) ions. Each of the two terminal cobalt centers, $\mathrm{Co} 1$ and $\mathrm{Co} 3$, is clearly low spin octahedral cobalt(III) with short Co-N distances (av. $1.911 \AA$ ). Co1 has a six coordinate pseudo octahedral geometry in which $\mathrm{N} 2, \mathrm{~N} 3, \mathrm{~N} 4$ and $\mathrm{N} 5$ atoms of the deprotonated di-Schiff base $\left[\mathrm{L}_{1}\right]^{2-}$ constitute the equatorial plane and two $\mathrm{Cl}[1$ and 2] atoms define the axial directions of the trans isomer. The analysis of bond angle values Table 2 suggests a small deviation from the expected octahedral geometry. This is due to the restrictions imposed by the tetradentate ligand $\left[\mathrm{L}_{1}\right]^{2-}$, the five- and six-membered chelate ring bite angles being $82^{\circ}$ and $98^{\circ}$, respectively. The coordination environment around $\mathrm{Co} 3$ is very similar to that of $\mathrm{Co} 1 . \mathrm{Co} 3$ is also in a pseudo octahedral environment in which the $\left[\mathrm{L}_{1}\right]^{2-}$ ligand forms the equatorial plane $[\mathrm{N}(8), \mathrm{N}(9), \mathrm{N}(10)$, $\mathrm{N}(11)]$ and the two apical positions are occupied by two $\mathrm{Cl}$-atoms [Cl3, Cl4]; here the five- and six-membered chelate ring bite angles are $82^{\circ}$ and $97^{\circ}$, respectively.

Two of these mononuclear anionic $\left[\text { trans }-\mathrm{Co}\left(\mathrm{L}_{1}\right) \mathrm{Cl}_{2}\right]^{-}$ complexes act as ligands to the central cobalt(II) center, [Co2] with the formation of four pyrazolate bridges. The
Table 2

Selected bond distances $(\AA)$ and angles $\left({ }^{\circ}\right)$ involving $\mathbf{1}$ and $\mathbf{4}$

\begin{tabular}{|c|c|c|c|}
\hline \multicolumn{2}{|l|}{1} & \multicolumn{2}{|l|}{4} \\
\hline \multicolumn{4}{|c|}{ Bond distances $(\stackrel{\AA}{)})$} \\
\hline Co1-N2 & $1.891(11)$ & $\mathrm{Co}-\mathrm{N}(1)$ & $1.902(3)$ \\
\hline Col-N3 & $1.943(12)$ & $\mathrm{Co}-\mathrm{N}(1) \# 1$ & $1.902(3)$ \\
\hline Co1-N4 & $1.963(13)$ & $\mathrm{Co}-\mathrm{N}(3) \# 1$ & $1.945(3)$ \\
\hline Col-N5 & $1.875(10)$ & $\mathrm{Co}-\mathrm{N}(3)$ & $1.945(3)$ \\
\hline $\mathrm{Co} 2-\mathrm{N} 1$ & $1.999(9)$ & $\mathrm{Co}-\mathrm{N}(4) \# 1$ & $1.972(3)$ \\
\hline $\mathrm{Co} 2-\mathrm{N} 6$ & $1.979(11)$ & $\mathrm{Co}-\mathrm{N}(4)$ & $1.972(3)$ \\
\hline $\mathrm{Co} 2-\mathrm{N} 7$ & $1.992(10)$ & & \\
\hline $\mathrm{Co} 2-\mathrm{N} 12$ & $2.002(10)$ & & \\
\hline $\mathrm{Co} 3-\mathrm{Cl} 3$ & $2.226(5)$ & & \\
\hline $\mathrm{Co} 3-\mathrm{Cl} 4$ & $2.249(5)$ & & \\
\hline $\mathrm{Co} 3-\mathrm{N} 8$ & $1.884(10)$ & & \\
\hline Co3-N9 & $1.925(16)$ & & \\
\hline Co3-N10 & $1.917(16)$ & & \\
\hline Co3-N11 & $1.889(10)$ & & \\
\hline \multicolumn{4}{|l|}{ Bond angles $\left({ }^{\circ}\right)$} \\
\hline N2-Co1-N3 & $81.8(5)$ & $\mathrm{N}(1)-\mathrm{Co}-\mathrm{N}(1) \# 1$ & $92.70(18)$ \\
\hline N2-Co1-N4 & $178.9(4)$ & $\mathrm{N}(1)-\mathrm{Co}-\mathrm{N}(3) \# 1$ & $94.87(13)$ \\
\hline N2-Co1-N5 & $98.7(5)$ & $\mathrm{N}(1) \# 1-\mathrm{Co}-\mathrm{N}(3) \# 1$ & $82.00(13)$ \\
\hline N3-Co1-N4 & $97.6(5)$ & $\mathrm{N}(1)-\mathrm{Co}-\mathrm{N}(3)$ & $82.00(13)$ \\
\hline N3-Co1-N5 & $179.4(5)$ & $\mathrm{N}(1) \# 1-\mathrm{Co}-\mathrm{N}(3)$ & $94.87(13)$ \\
\hline N4-Co1-N5 & $81.9(5)$ & $\mathrm{N}(3) \# 1-\mathrm{Co}-\mathrm{N}(3)$ & $175.49(17)$ \\
\hline N1-Co2-N6 & $102.7(4)$ & $\mathrm{N}(1)-\mathrm{Co}-\mathrm{N}(4) \# 1$ & $87.92(14)$ \\
\hline $\mathrm{N} 1-\mathrm{Co} 2-\mathrm{N} 7$ & $117.2(4)$ & $\mathrm{N}(1) \# 1-\mathrm{Co}-\mathrm{N}(4) \# 1$ & $177.55(13)$ \\
\hline N1-Co2-N12 & 107.3(4) & $\mathrm{N}(3) \# 1-\mathrm{Co}-\mathrm{N}(4) \# 1$ & $95.59(13)$ \\
\hline N6-Co2-N7 & $110.0(4)$ & $\mathrm{N}(3)-\mathrm{Co}-\mathrm{N}(4) \# 1$ & $87.56(13)$ \\
\hline N6-Co2-N12 & $117.0(4)$ & $\mathrm{N}(1)-\mathrm{Co}-\mathrm{N}(4)$ & $177.55(13)$ \\
\hline N7-Co2-N12 & $103.3(4)$ & $\mathrm{N}(1) \# 1-\mathrm{Co}-\mathrm{N}(4)$ & $87.92(14)$ \\
\hline N8-Co3-N9 & $82.8(6)$ & $\mathrm{N}(3) \# 1-\mathrm{Co}-\mathrm{N}(4)$ & $87.57(13)$ \\
\hline N8-Co3-N10 & $178.8(6)$ & $\mathrm{N}(3)-\mathrm{Co}-\mathrm{N}(4)$ & $95.59(13)$ \\
\hline N8-Co3-N11 & $99.3(5)$ & $\mathrm{N}(4) \# 1-\mathrm{Co}-\mathrm{N}(4)$ & $91.60(2)$ \\
\hline N9-Co3-N10 & $96.0(7)$ & & \\
\hline N9-Co3-N11 & $177.8(6)$ & & \\
\hline $\mathrm{N} 10-\mathrm{Co} 3-\mathrm{N} 11$ & $81.9(6)$ & & \\
\hline
\end{tabular}

metal ion sits in a slightly flattened tetrahedral geometry with an average Co2-N distance of $1.993 \AA$ and an average chelate bite angle of $103^{\circ}$. The angle between the N1-Co2$\mathrm{N} 6$ and N7-Co2-N12 chelate planes is $84^{\circ}$. This orthogonality in approach of the two ligands (obviously terminal octahedral complexes) is a consequence of the steric

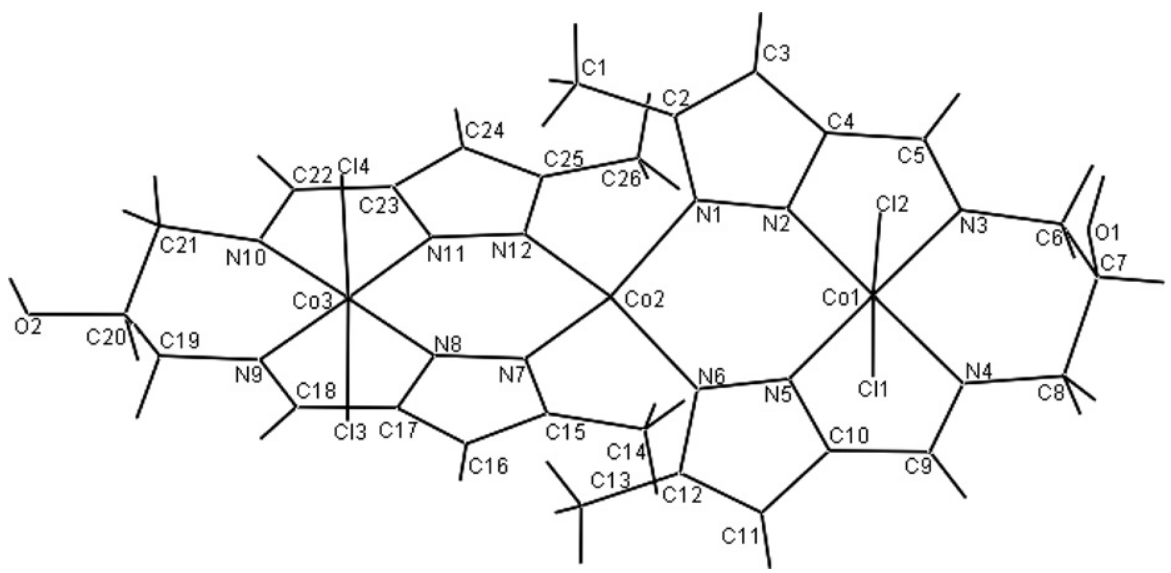

Fig. 2. Molecular structure of $\mathbf{1}$. 
hindrance of the interlacing methyl groups on the pyrazole rings. These methyl groups also effectively prevent the central $\mathrm{Co}(\mathrm{II})$ ion from adopting a higher coordination number.

The Co1 ‥Co 2 and $\mathrm{Co} 2 \cdots \mathrm{Co} 3$ interatomic distances are $3.794 \AA$ and $3.791 \AA$, respectively. None of these distances is sufficiently short to imply any metal-metal bonding or allow intra-metal spin exchange through mutual interactions [16-18]. In the present complex, the Co(II)$\mathrm{N}$ distances vary from 1.979(9) to 2.004(10) $\mathrm{\AA}$, and are typical for high spin $\mathrm{Co}(\mathrm{II})-\mathrm{N}$ distances. The $\mathrm{Co}(\mathrm{III})-\mathrm{N}$ distances are in the range 1.874(10)-1.963(11) $\AA$, as expected for low spin Co(III) $[16,19]$. Thus the bond lengths about the terminal cobalt ions are significantly shorter than those about the central cobalt ion, indicating that the terminal ones are trivalent while the central one is divalent.

A perspective view of compound 4, including the atomnumbering scheme, is shown in Fig. 3. The asymmetric unit consists of a $\left[\mathrm{Co}(\mathrm{L})_{2}\right]^{+}$cation and $\mathrm{ClO}_{4}{ }^{-}$anion. In the crystal structure the two potentially uninegative tridentate (NNN) donor ligand molecules form an octahedral geometry around the central cobalt atom. Each ligand molecule offers its respective deprotonated pyrazolyl nitrogen, azoimine nitrogen and terminal primary nitrogen atoms as the coordination sites, providing an $\mathrm{N}_{6}$ chromophore. The equatorial plane of the octahedral geometry is defined by N1(deprotonated pyrazolide), N3(azoimine), N4(primary $\mathrm{NH}_{2}$ ) and $\mathrm{N} 3 \mathrm{a}$ (azoimine), and the two apical positions are coordinated by N1a (deprotonated pyrazolide) and $\mathrm{N} 4 \mathrm{a}$ (primary $\mathrm{NH}_{2}$ ). The coordination polyhedron of the said complex is best described as a distorted octahedron, which is reflected through the difference in $\mathrm{N}-\mathrm{Co}-$ $\mathrm{N}$ bond angles. Quite obviously all the bond angles are deviated from the respective ideal bond angle values. The maximum deviation occurs for $\mathrm{N} 1-\mathrm{Co}-\mathrm{N} 3\left[82.00(13)^{\circ}\right]$,

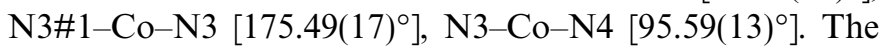
two Co-N pyrazolide bonds, being equal in length [1.902(3) $\AA$ ] , are still shorter than the two equal Co-N(azoimine) bonds $[1.945(3) \AA]$. This difference in bond lengths is quite evident from the difference in the basic property between the deprotonated pyrazolide nitrogen (stronger

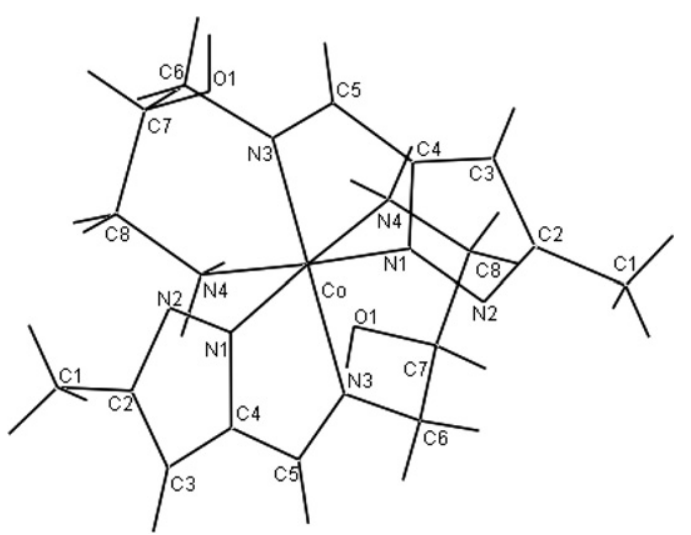

Fig. 3. Molecular structure of 4. base) and the neutral azoimine nitrogen (weaker base). The other two $\mathrm{Co}-\mathrm{N}$ (terminal $\mathrm{NH}_{2}$ ) bonds are also equal $[1.972(3) \AA]$ in themselves, but are longer than the other $\mathrm{Co}-\mathrm{N}$ bonds. This is because of the difference in hybridization state $\left(\mathrm{sp}^{2}\right.$ for azoimine nitrogen and $\mathrm{sp}^{3}$ for terminal $\mathrm{NH}_{2}$ ). The two ligand molecules approach the central metal ion almost orthogonally, as suggested from the dihedral angle analysis (the dihedral angle being $88^{\circ}$ ). The ligands are coordinated to the central $\mathrm{Co}$ (III) ion in the meridional fashion (the pyrazolide and primary amine nitrogen atoms are cis to each other and the azoimine nitrogen atoms are trans). The origin of this meridional disposition arises from the maximum back bonding effect between the filled $t_{2 \mathrm{~g}}$ orbitals on the $\mathrm{Co}$ (III) ion and the vacant $\pi^{*}$ M.O.s on the pyrazole ring. The perchlorate anion in this structure lies proximate to an inversion center. The crystal structure is stabilized through a network of both intramolecular and intermolecular H-bonding. The uncoordinated-OH of one ligand HL (in one asymmetric unit) forms a strong intermolecular $\mathrm{H}$-bond with the pyrazolide $\mathrm{N}$ of another asymmetric unit [the $\mathrm{O}-\mathrm{N}$ distance being $2.755(5) \AA]$. Likewise, the N4-O1 contact [3.011(5) $\AA$ ] is also an indication of weak intramolecular $\mathrm{H}$-bonding. The details of $\mathrm{H}$-bond parameters are presented in Table 3. For clarity, the H-bonding interaction is shown in Fig. 4.

\subsection{Diffuse reflectance and solution spectra}

The spectral pattern in both DRS and in methanol solution of 1 (as a representative example) exhibits bands mainly characteristic of cobalt(II) in a tetrahedral geome-

Table 3

Hydrogen bonds for $4(\AA)$ and $\left(^{\circ}\right)$

\begin{tabular}{lllll}
\hline $\mathrm{D}-\mathrm{H} \cdots \mathrm{A}$ & $d(\mathrm{D}-\mathrm{H})$ & $d(\mathrm{H} \cdots \mathrm{A})$ & $d(\mathrm{D} \cdots \mathrm{A})$ & $\angle(\mathrm{DHA})$ \\
\hline $\mathrm{O}(1)-\mathrm{H}(1 \mathrm{~A}) \cdots \mathrm{N}(2) \# 1$ & 0.82 & 1.94 & $2.760(4)$ & 176.2 \\
$\mathrm{~N}(4)-\mathrm{H}(4 \mathrm{~A}) \cdots \mathrm{O}(1) \# 2$ & 0.90 & 2.33 & $3.007(5)$ & 132.3 \\
\hline
\end{tabular}

Symmetry transformations used to generate equivalent atoms:

$\# 1 x-1 / 2, y-1 / 2, z$. \#2 $-x+1, y,-z+1 / 2$.

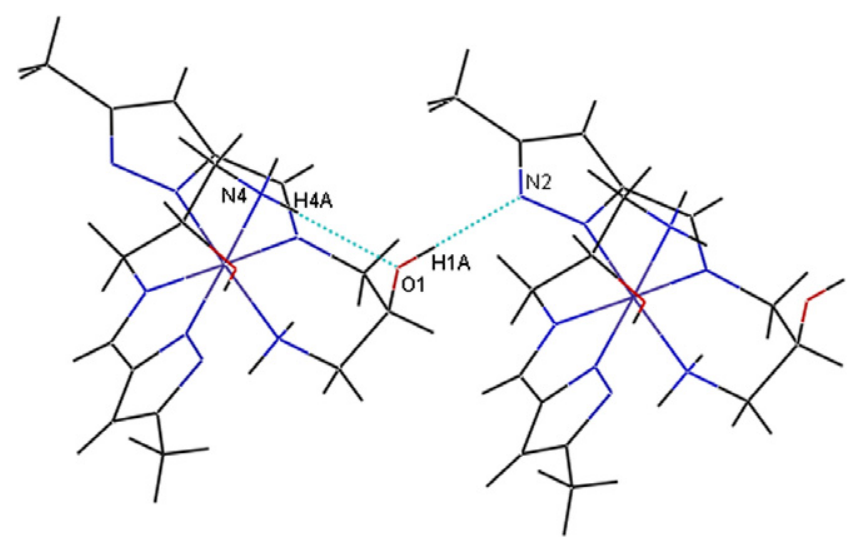

Fig. 4. H-bonding of 4. 
try. In the diffuse reflectance spectrum, in addition to the tetrahedral bands, (one spanning between $600-650 \mathrm{~nm}$ and the other between $1000-1100 \mathrm{~nm}$ ) another spectral band is observed at $c a .400 \mathrm{~nm}$, attributable to the low-spin octahedral $\mathrm{Co}$ (III) center. In solution, however, only $\mathrm{Co}$ (II) tetrahedral bands are obtained. Although three spin-allowed electronic transitions are expected to occur for tetrahedral $\mathrm{Co}(\mathrm{II})$, the visible spectrum is actually dominated by the highest energy transition, ${ }^{4} \mathrm{~A}_{2} \rightarrow{ }^{4} \mathrm{~T}_{1}(\mathrm{P})$ with the ${ }^{4} \mathrm{~A}_{2} \rightarrow{ }^{4} \mathrm{~T}_{1}(\mathrm{~F})$ transition in the near IR region. The visible transition in tetrahedral complexes generally has complex envelopes because a number of transitions to doublet excited states occur in the same region, and these acquire some intensity by means of spin-orbit coupling. Thus from the above discussion it may be stated that, both in solid and in solution the weak absorption band at $c a .1065 \mathrm{~nm}$ and the strong one at $c a 620 \mathrm{~nm}$ may be assigned as ${ }^{4} \mathrm{~A}_{2} \rightarrow{ }^{4} \mathrm{~T}_{1}(\mathrm{~F})\left(v_{2}\right)$ and ${ }^{4} \mathrm{~A}_{2} \rightarrow{ }^{4} \mathrm{~T}_{1}(\mathrm{P})\left(v_{3}\right)$, respectively.

The diffuse reflectance spectrum of 3 exhibits two broad bands at $373 \mathrm{~nm}$ and $462 \mathrm{~nm}$ corresponding to two spinallowed transitions $\left({ }^{1} \mathrm{~A}_{1 \mathrm{~g}} \rightarrow{ }^{1} \mathrm{~T}_{2 \mathrm{~g}}\right.$ and $\left.{ }^{1} \mathrm{~A}_{1 \mathrm{~g}} \rightarrow{ }^{1} \mathrm{~T}_{1 \mathrm{~g}}\right)$ for the low spin $\mathrm{Co}(\mathrm{III})$ octahedral species. The DMF solution of the complex does not display any band in the visible region. The $\mathrm{d}-\mathrm{d}$ bands in the electronic spectrum of the present $\mathrm{Co}(\mathrm{III})$ complex is obscured by the intense $\mathrm{CT}$ bands [20].

The diffuse reflectance spectrum of $\mathbf{4}$ (as a representative example), exhibiting two bands at $368 \mathrm{~nm}\left({ }^{1} \mathrm{~A}_{1 \mathrm{~g}} \rightarrow{ }^{1} \mathrm{~T}_{2 \mathrm{~g}}\right)$ and $453 \mathrm{~nm}\left({ }^{1} \mathrm{~A}_{1 \mathrm{~g}} \rightarrow{ }^{1} \mathrm{~T}_{1 \mathrm{~g}}\right)$, indicates the low-spin octahedral geometry of the $\left[\mathrm{Co}(\mathrm{L})_{2}\right]^{+}$cation. The intense charge-transfer bands in the UV-region probably mask the other bands. The DMF solution of the complex displays a characteristic absorption in the UV-Vis region. The characteristic visible spectrum may be ascribed to transitions from ${ }^{1} \mathrm{~A}_{1 \mathrm{~g}}$ to ${ }^{1} \mathrm{~T}_{1 \mathrm{~g}}$ and ${ }^{1} \mathrm{~T}_{2 \mathrm{~g}}$ states, respectively. Here only one band at $449 \mathrm{~nm}\left({ }^{1} \mathrm{~A}_{1 \mathrm{~g}} \rightarrow{ }^{1} \mathrm{~T}_{1 \mathrm{~g}}\right)$ is obtained. The second transition is obscured by either intense charge transfer bands or intraligand transitions [20].

\subsection{Electrochemistry}

The cyclic voltammetry experiment of $\mathbf{1}$ (Fig. 5) was performed in methanol solution within the potential range $\pm 2 \mathrm{~V}$ versus $\mathrm{Pt}$ wire electrode at ambient temperature $(300 \mathrm{~K})$ using a three-electrode configuration. The complex exhibits no oxidation response. However, an irreversible reduction couple at $-1.11 \mathrm{~V}$ is ascribed to a $\mathrm{Co}(\mathrm{III}) \rightarrow \mathrm{Co}$ (II) reduction. The redox signal remains almost unaltered under different scan rates $\left(0.02-1.0 \mathrm{vs}^{-1}\right)$ in the temperature range $300-280 \mathrm{~K}$.

\subsection{Magnetic and EPR study of 1 and 2}

The magnetic properties of compounds $\mathbf{1}$ and $\mathbf{2}$ are as expected, taking into account the linear trinuclear mixed valence cobalt(III/II/III) (Fig. 2) in which the surrounding Co(III) centres have an octahedral geometry with $S=0$

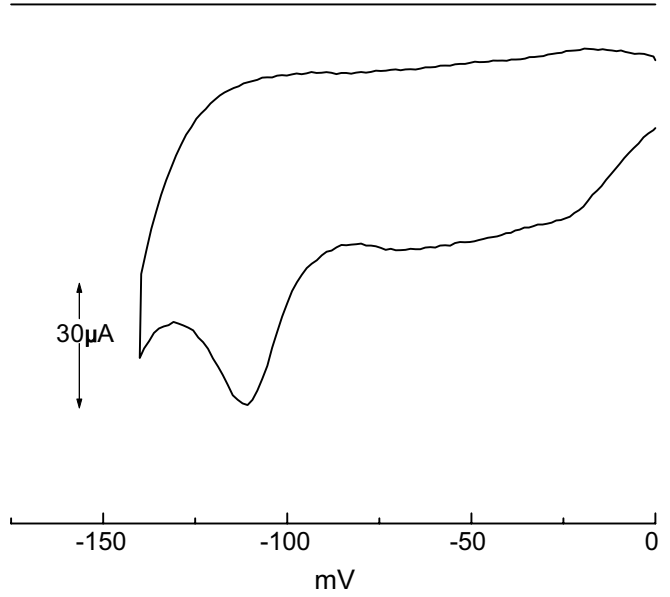

Fig. 5. Cyclic voltammogram of $\mathbf{1}$.

and the central $\mathrm{Co}$ (II) centre has a distorted tetrahedral geometry possessing spin $(S=3 / 2)$ without spin-orbit splitting. Susceptibility measurements in the $300-2 \mathrm{~K}$ range shows a constant $\chi_{\mathrm{M}} \mathrm{T}$ value of 2.293 and $2.458 \mathrm{~cm}^{3}$ $\mathrm{K} \mathrm{mol}^{-1}$, down to approximately 65 and $50 \mathrm{~K}$, respectively, and below this temperature decrease to 1.373 and $1.476 \mathrm{~cm}^{3} \mathrm{~K} \mathrm{~mol}^{-1}$ at $2 \mathrm{~K}$ for $\mathbf{1}$ and $\mathbf{2}$, respectively (Fig. 6). Structural data of compound $\mathbf{1}$ indicate that it is a linear trinuclear cobalt complex with pyrazolate bridges and the main factor determining the decrease in the $\chi_{\mathrm{M}} T$ value could be the Zero Field Splitting (ZFS) of the cobal$t(I I)$ ion in a distorted tetrahedral environment. To determine this parameter, we have fitted the experimental data to the following expression [21]:

$$
\begin{aligned}
\chi_{\mathrm{M}}=\{[ & \left.\mathrm{Ng}^{2} \mu_{\beta}^{2} / K T\right]\left[(1 / 4)\left(1+9 e^{-2 x}\right) /\left(1+e^{-2 x}\right)\right] \\
& \left.+2\left[1+(3 / 4 x)\left(1-e^{-2 x}\right) /\left(1+e^{-2 x}\right)\right]\right\} / 3
\end{aligned}
$$

where $x=D / K T$.

The best fit parameters obtained minimizing the function $R=\left(\sum \chi_{\mathrm{M}} T_{\text {calc }}-\chi_{\mathrm{M}} T_{\text {obs }}\right)^{2} /\left(\sum \chi_{\mathrm{M}} T_{\text {obs }}\right)^{2}$ are $D=$ $16.1 \mathrm{~cm}^{-1}, g=2.21$ for 1 and $D=12.3 \mathrm{~cm}^{-1}, g=2.28$ for

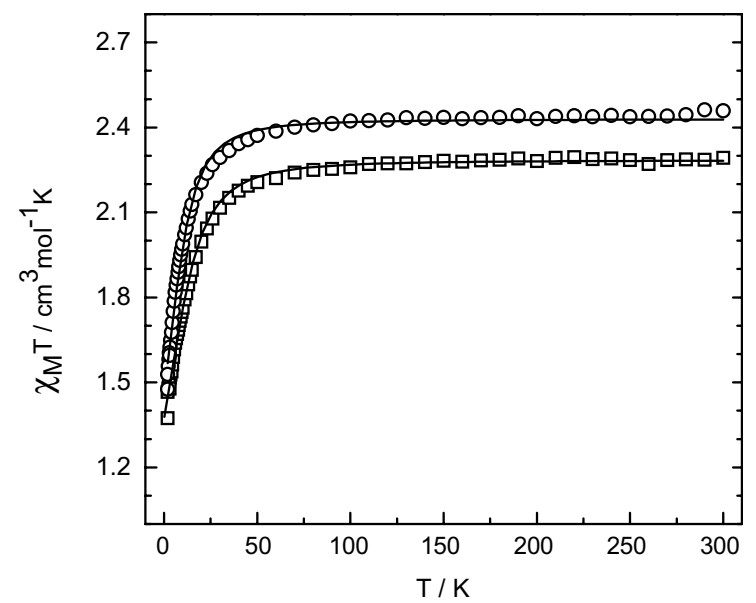

Fig. 6. Plot of $\chi_{\mathrm{M}} T$ vs. $T$ of a polycrystalline sample of $\mathbf{1}(\square)$ and $\mathbf{2}(\bigcirc)$. The solid line corresponds to the best fit. 
2. In both cases the $R$ factor value is found to be inferior to $10^{-5}$. It should be pointed out that these $\mathrm{D}$ values seem to be too high because in the fits we do not take into account the intermolecular interactions (currently AF).

The field dependence of magnetization $(0-5 \mathrm{~T})$ measured at $2 \mathrm{~K}$ is shown in Fig. 7 in the form of $\mathrm{M} / \mathrm{N} \beta$ per $\mathrm{Co}(\mathrm{III})-$ $\mathrm{Co}(\mathrm{II})-\mathrm{Co}(\mathrm{III})$ unit versus $\mathrm{H}$. The magnetization reaches a value of 1.91 and 2.25 electrons at $5 \mathrm{~T}$ for $\mathbf{1}$ and $\mathbf{2}$, respectively. Comparison of the overall shape of the experimental plots with the Brillouin plot (solid plot) for one isolated ion with $S=3 / 2$ system and $g=2$ indicates slower magnetization, which is consistent with the presence of the ZFS effect.

The powder EPR spectra of $\mathbf{1}$ and $\mathbf{2}$ at $4 \mathrm{~K}$ are shown in Fig. 8. They exhibit a resonance with a maximum at approximately $g=4.80$ and 5.13 and a broad band centred at $g=2.16$ and 2.24 for $\mathbf{1}$ and $\mathbf{2}$, respectively. No new transition is observed when the temperature is increased. These spectra are in good agreement with those expected for a $S_{T}=3 / 2$ system: the spectrum at low temperature is associated with the Kramer doublet $\pm 1 / 2$ arising from the $S=3 / 2$ ground state $[22,23]$, which must present two signals approximately in the ratio $g_{\perp}=2 g_{\|}$.

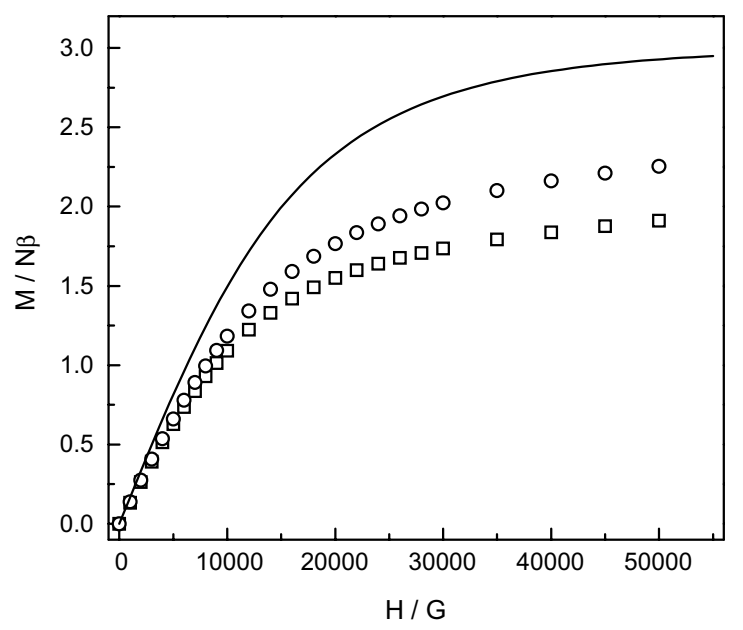

Fig. 7. Plot of reduced magnetization $\mathrm{M} / \mathrm{N} \beta$ vs. applied field $\mathrm{H}$ at $2 \mathrm{~K}$ for $1(\square)$ and $2(\bigcirc)$. Solid line corresponds to the Brillouin function for an isolated $S=3 / 2$ with $g=2.0$.

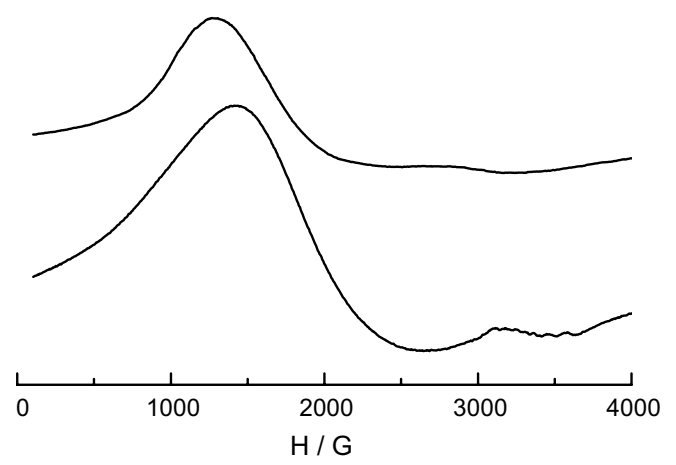

Fig. 8. Polycrystalline powder EPR spectra of $\mathbf{1}$ (bottom) and $\mathbf{2}$ (top) at $4 \mathrm{~K}$.

\section{Conclusion}

The peculiarity of the coordinating behaviour of the same Schiff base $\left(\mathrm{H}_{2} \mathrm{~L}_{1}\right)$ towards $\mathrm{Cu}(\mathrm{II})$ and $\mathrm{Ni}(\mathrm{II})$ metal ions has already been reported in our earlier paper [10]. There we found that the composition of the metal complexes depends upon two factors - firstly the mole proportion of each of the aldehyde (MPA), the diamine (DAP) and the metal salt used and secondly the specification of the metal used. The compositions as well as internal cyclisation (in part) leading to the formation of a new ligand system are also related to the nature of the anion of the metal salt used [10]. This peculiarity was exclusively specific for the $\mathrm{Cu}(\mathrm{II})$ ion. Tracing the same synthetic route for the $\mathrm{Co}(\mathrm{II})$ ion, we find a different but unusual observation.

Using the aldehyde and amine (2:1 equiv.) and 1 equiv. of the $\mathrm{Co}$ (II) salts in the presence of $\mathrm{Cl}^{-}$and $\mathrm{Br}^{-}$ions, unusual linear trinuclear mixed valence $\mathrm{Co}(\mathrm{III} / \mathrm{II} / \mathrm{III}) \mathrm{com}$ plexes of $\mathrm{H}_{2} \mathrm{~L}_{1}$ are isolated, unlike the mononuclear $\mathrm{Cu}$ (II) complexes of $\mathrm{H}_{2} \mathrm{~L}_{1}$ formed earlier in a similar reaction [10]. A mononuclear complex of $\mathrm{Co}$ (III) is formed when the $\mathrm{CH}_{3} \mathrm{COO}^{-}$salt is used. Whereas the mixed ligand system $\left(\mathrm{HL}_{2}\right.$ and partially cyclised $\left.\mathrm{HL}_{1}\right)$, formed in situ by 1:1 condensation of MPA and DAP in the presence of $\mathrm{Cu}(\mathrm{II})$ nitrate, resulted in a tetra $\mathrm{Cu}$ (II) complex, and the same reaction when carried out with $\mathrm{Ni}(\mathrm{II})$ salts $\mathrm{ClO}_{4}^{-}, \mathrm{NO}_{3}{ }^{-}$andBF ${ }_{4}^{-}$formed intractable materials in our earlier work [10], whilst in the present study for $\mathrm{Co}(\mathrm{III})$ using the same counter ions the usual mononuclear bischelate complexes are isolated. When $\mathrm{Cl}^{-}$and $\mathrm{Br}^{-}$anions were used as counterions in this latest study, an intractable material was isolated.

\section{Acknowledgements}

Financial support [F. 30-65/2004(SR)] from the University Grants Commission, New Delhi, India, is gratefully acknowledged. Mohamed Salah El Fallah is grateful for the Grants sanctioned by the Ministerio de Ciencia y Tecnología (Programa Ramón y Cajal) and BQU2003/00539.

\section{Appendix A. Supplementary material}

CCDC 645553 and 645554 contain the supplementary crystallographic data for $\mathbf{1}$ and $\mathbf{4}$. These data can be obtained free of charge via http://www.ccdc.cam.ac.uk/ conts/retrieving.html, or from the Cambridge Crystallographic Data Centre, 12 Union Road, Cambridge CB2 1EZ, UK; fax: (+44) 1223-336-033; or e-mail: deposit @accdc.cam.ac.uk. Supplementary data associated with this article can be found, in the online version, at doi:10.1016/ j.poly.2007.09.037.

\section{References}

[1] (a) B. Meunier (Ed.), Biomimetic Oxidations Catalysed by Transition Metals, Imperial College Press, London, 2000; 
(b) C. Christmas, J.B. Vincent, H.R. Chang, J.C. Huffman, G Christau, D.N. Hendrickson, J. Am. Chem. Soc. 10 (1988) 823;

(c) A. Nishinaga, T. Yamada, H. Fujisawa, K. Ishizaki, H. Ihara, T. Matsuura, J. Mol. Catal. 48 (1988) 249;

(d) R.H. Holm, P. Kennepohl, E.I. Solomon, Chem. Rev. 96 (1996) 2239.

[2] S.J. Lippard, J.M. Berg, Principles of Bioinorganic Chemistry, University Science Books, Mill Valley, CA, 1994.

[3] (a) L. Chun, C.R. Kagan, J. Am. Chem. Soc. 125 (2003) 336;

(b) A. Bousseksou, G. Molnar, P. Demont, J. Menegotto, J. Mater. Chem. 13 (2003) 2069;

(c) J.S. Miller, Inorg. Chem. 39 (2000) 4392.

[4] J.-Y. Qi, H.-X. Ma, X.-J. Li, Z.-Y.M. Zhou, C.K. Choi, A.S.C. Chan, Q.-Y. Yang, Chem. Commun. (2003) 1294.

[5] H. Nusbaumer, J.-E. Moser, S.M. Zakeeruddin, M.K. Nazeeruddin, M. Grätzel, J. Phys. Chem. B 105 (2001) 10461.

[6] A. BÖttcher, T. Takeuchi, K.I. Hardcastle, T.J. Meade, H.B. Gray, D. Cwikel, M. Kapon, Z. Dori, Inorg. Chem. 36 (1997) 2498.

[7] M. Murrie, S.J. Teat, H. Stoeckli-Evans, H.U. Güdel, Angew. Chem., Int. Ed. 42 (2003) 4653.

[8] T. Szymanska-Buzar, J.J. Ziolkowski, J. Mol. Catal. 11 (1981) 371.

[9] D.E. Babushkin, E.P. Talsi, J. Mol. Catal. A 130 (1998) 131.

[10] S. Pal, A.K. Barik, S. Gupta, A. Hazra, S.K. Kar, S.M. Peng, G.H Lee, R.J. Butcher, M.S.E. Fallah, J. Ribas, Inorg. Chem. 44 (2005) 3880 .
[11] A.K. Barik, S. Paul, S.K. Kar, R.J. Butcher, J.C. Brayan, Polyhedron 18 (1999) 571.

[12] D.D. Perrin, W.L.F. Armargo, D.R. Perrin, Purification of Laboratory Chemicals, 2nd ed., Pergamon Prees, Oxford, 1980.

[13] Bruker, SAINT v7.34A, Bruker AXS Inc., Madison, WI, USA, 2005.

[14] Bruker, SHelXTl v6.12, Bruker AXS Inc., Madison, WI, USA, 2000.

[15] G.M. Sheldrick, SHELXL-97, Programs for Crystal Structure Solution and Refinement, University of Göttingen, Germany 1997.

[16] S. Chattopadhyay, G. Bocelli, A. Musatti, A. Ghosh, Inorg. Chem. Commun. 9 (2006) 1053.

[17] A. Gerli, K.S. Hagen, L.G. Marzilli, Inorg. Chem. 30 (1991) 4673.

[18] H. Kobayashi, K. Okhi, I. Tsujikawa, K. Osaki, N. Uryu, Bull. Chem. Soc. Jpn. 49 (1976) 1210.

[19] T.S. Billson, J.D. Crane, O.D. Fox, S.L. Heath, Inorg. Chem. Commun. 3 (2000) 718.

[20] A.K. Barik, S. Paul, R.J. Butcher, S.K. Kar, Polyhedron 19 (2000) 2651.

[21] O. Khan, Molecular Magnetism, VCH Publishers, New York, 1993, p. 21.

[22] J. Ribas (Ed.), Quimica de Coordination, S.A. Omega, Bercelona, 2000 , p. 525.

[23] R. Vicente Escuer, J. Ribas, Polyhedron 11 (1992) 857. 